\section{İŞIN ANLAMI KAVRAMI VE TERCÜME BİR ÖLÇEĞİN TÜRKÇE'DE GEÇERLIIK VE GÜVENIRLIK ANALIZİ}

\author{
Makale Gönderim Tarihi: 23.03.2017 \\ Mine AFACAN \\ FINDIKLI \\ Doç. Dr. \\ Beykent Üniversitesi, \\ İktisadi ve İdari Bilimler \\ Fakültesi \\ minefindikli@beykent.edu.tr
}

Hatice Necla KELEŞ

Doç. Dr.

Bahçeşehir Üniversitesi,

Sağlık Bilimleri Fakültesi

necla.keles@vs.bau.edu.tr

Ceyda AFACAN

Doktora Öğrencisi

Mimar Sinan Güzel Sanatlar

Üniversitesi,

Fen Bilimleri Enstitüsü

istatistiksel@gmail.com
Yayına Kabul Tarihi: 02.10.2017

ÖZI

$\mathrm{Bu}$ araştırmanın amacı çalışanların iş anlam algısının ölçülmesinde Steger ve arkadaşları tarafindan geliştirilen "İşin Anlamı Ölçeği"nin Türkçe geçerleme çalışmasının yapılmasıdır. Keşfedici Faktör Analizi ile Türkiye örnekleminde yapı geçerliliği ortaya çıkarılmış ve daha önceki çalışmaların aksine tek faktörlü bir yapı elde edilmiştir. Daha sonra Doğrulayıcı Faktör analizi ile sınanmış ve yapı doğrulanmıştır. Madde analizi ve iç tutarlılık bulguları yüksek kabul edilebilir seviyededir. Ölçeğin Türkçe'de güvenirlik ve geçerliğini değerlendiren çalışma kapsamındaki uygulama ve analizler sonucunda on soruluk tek faktör yapısıyla geçerli ve güvenilir olduğu belirlenmiştir.

Dili de oldukça anlaşılır olan ölçeğin işin anlamı ile ilgili olarak Türkçe yazında yapılacak araştırmalara katk1 sağlayacağı düşünülmektedir.

Anahtar Kelimeler: İşin Anlamı Ölçeği, Türkçe Uyarlama, Geçerlik ve Güvenirlik

JEL Kodu: M54, M52, M10

Alanı: İsletme

Türü: Araştırma

DOI:10.9775/kauiibfd.2017.018

Atıfta bulunmak için: Fındıklı, M, A., Keleş, H, N. \& Afacan, C. (2017) İşinanlamıkavramı ve tercüme bir ölçeğin Türkçe'de geçerlik ve güvenirlik analizi,

KAÜIIBBFD 8(16), 395-413. 


\title{
WORK MEANING CONCEPT AND A TRANSLATION SCALE ANALYSIS OF VALIDITY AND RELIABILITY IN TURKISH VERSION
}

\author{
Kafkas Üniversity \\ Economics and Administrative \\ Sciences Faculty \\ KAUJAESF \\ Vol. 8, Issue 16, 2017 \\ ISSN: $1309-4289$ \\ E - ISSN: 2149-9136

ABSTRACT The aim of this research is to

Mine AFACAN

FINDIKLI

Assoc. Prof.

Beykent University

Faculty of Economics and

Administrative Sciences

minefindikli@beykent.edu.tr

Hatice Necla KELEŞ

Assoc. Prof.

Bahçeşehir Üniversitesi

Faculty of Health

necla.keles@vs.bau.edu.tr

\section{Ceyda AFACAN}

$\mathrm{PhD}$. Student

Mimar Sinan Fine Arts

University, Institute of

Science and Technology istatistiksel@gmail.com

\begin{abstract}
use the "Work And Meaning Inventory" developed by Steger et al. adapting to Turkish literature. Exploratory Factor Analysis, construct validity was revealed in the sample of Turkey and a single factor structure was obtained unlike the previous studies. It was then tested with the Confirmatory Factor Analysis and the structure was verified. Item analysis and internal consistency are highly acceptable.Turkish determined to be valid and reliable with a single factor structure of ten items in content of research.

It is thought that the scale, which is also quite comprehensible language, will contribute to the research to be done in the Turkish literature about the work and meaning.
\end{abstract}

Keywords: Work And Meaning Inventory, Turkish version, Reliability and Validity.

Jel codes: M54, M52, M10,

Scope: Business

Type: Research

Cite this Paper: : Findıklı, M, A., Keleş, H, N. \& Afacan, C. (2017)

Workmeaningconcept and a translation scale analysis of validity and reliability in Turkishversion,

KAUJAESF 8(16), 395-413. 


\section{GİRİs}

Hayatı yașanmaya değer kılan faktörler insanın var oluşundan bu yana sürekli merak konusu olmuş ve "yaşanmaya değer" bir hayatın aslında insanın var oluşuna anlam katmasıyla mümkün olabileceği Frankl tarafindan (1984) ifade edilmiştir. Bu bakış açısı çerçevesinde "anlam" arayışının, insanın en temel motivasyon aracı olduğu Sezer (2012) tarafından öne sürülmüştür. Günümüzde yaşanan sosyo-ekonomik gelişmelerle birlikte, bireyin "anlam arayışı" toplum ve iş yaşamı içerisindeki rollerini yeniden sorgulamasına neden olmaktadır (Kesken \& Ünnü, 2011, s. 12).

Anlam kavram1, bireyin hayat1 boyunca yerine getirmek durumunda olduğu rolleri çerçevesinde, konum ve koşulların "an" lığına dikkat çekerek bütüncül ve sorumlu bir hayat felsefesi kazanılmasına yardımcı olmakta, bireyi sorumlu davranışa yönlendirmektedir (Bahadır, 2000, s. 2). Steger ve arkadaşları (2008) ise anlam arayışını; hayatın anlamı, önemi ve amacına yönelik bir anlayış oluşturma süreci olarak tanımlamaktadır. İnsan hayatının önemli bir kesitinin iş yaşamı olduğu dikkate alındığında, anlam arayışı iş yaşamı için de geçerli olmaktadır. Akademik yazında, hayatın anlamı ve/ veya işin anlamı kavramı ile psikolojik iyi oluş Melton ve Schulenberg (2008), Nielsen vd. (2008) , umut Feldman ve Snyder (2005), yaşam / iş doyumu Steger vd. (2012) ve örgütsel bağl1lık Mendes ve Stander (2011) ilişkilerini doğrulanmaktadır.

Gerek iş hayatında giderek yoğunlaşan $\mathrm{Y}$ kuşağı gerekse gençleşen işgücünün kişisel fayda beklentilerinin -sosyal ve ekonomik refah düzeyini yükseltme, iş-yaşam dengesi vb.- giderek artması sebebiyle, işe yüklenen anlam konusuna olan ilginin artış göstemektedir.

$\mathrm{Bu}$ bilgilerin 1şı̆̆1 altında, günümüzde toplumsal, psiko sosyal ve demografik açılardan günümüz iş dünyasında çalışan beklentilerindeki değişimin işin anlamı aracılığı ile bireysel ve örgütsel performansa önemli katkılar sağlayacağı öngörülmektedir. Ulusal yazın incelenecek olursa iş dünyasında son dönemlerde sıklıkla gündeme gelen işin anlamı kavramına yönelik araştırma sayısının kısıtlı olduğu görülecektir. Buradan hareketle mevcut ölçek uyarlaması araştırmasının, kavramın farklı sektörlerde yer alan işletmelerde farklı değişkenler ile olan ilişkisinin incelenmesi ile Türkçe yazına katkı sağlaması beklenmektedir.

\section{KURAMSAL ARKA PLAN}

\section{1. İşin Anlamı Kavramı}

Gerçekleştirilen akademik araştırmaların sonuçlarına göre, bireylerin anlam arayışlarında, üç temel soru etrafında (Nereye aitim?; başkaları ile nasıl ilişki kuruyorum? ve diğerlerine katkım, yarattığım değer nedir?) deneyimlerini düzenledikleri görülmekte (Chartwright \& Holmes, 2006, 201) tarafindan, ve 
"anlam" tanımlamalarında aile ve işlerinden yararlandıkları öne sürülmektedir (Garner \& Méda, 2006, s. 623). Ailenin bir ferdi olarak bireyin yaşamına anlam katan en büyük faktörün, bireyin iş yaşamı ve işine yüklediği anlam olduğu vurgulanmaktadır (Meitar, Carmeli, \& Waldman, 2009, s.363). Diğer araştırmalarda ise işin anlamı kavramına; bireylerin ve ait olunan toplumun faydasına olacak görev ve etkinliklerinin, çalışan açısından taşıdığı önem, inançlar ve tanımlar şeklinde açıklama getirilmektedir (Dimitrov 2012, 355-57. Yapılan tanımların yanı sıra yaşanan ekonomik, teknolojik ve sosyo-demografik değişimlerin işe yüklenen anlamı değişime uğrattığını ve bireyin iş, aile ve diğer yükümlülükleri ile ilgili yeni bir denge arayışına girdiğini iddia etmektedir (Pahl, 1994). Nitekim, işi anlamlı hale getiren iş özelliklerinin; işin topluma sağladığı katkı, iş ahlakı açısından yapılan işin yerine getirilmesinden çok, sonuçları açısından doğruluk içermesi, sürekli öğrenme ve kariyer gelişimi, otonomi, kaliteli iş ilişkileri, takdir edilme ve ödüllendirmeyi içinde barındırdığ ve bireyi psikolojik olduğu kadar fiziksel yönden de olumlu biçimde etkilediği ifade edilmektedir (Morin, 2008: 10). İşin anlamının yokluğunun ise özellikle 25-35 yaş arası çalışanlarda hayal kırıklığı ile birlikte gelen ve bir anlamda "Çeyrek Yaşam Krizi” olarak adlandırılan, birey ve örgütler açısından olumsuz çıktılara sebep olabileceği öne sürülmektedir (Chartwright \& Holmes, 2006, s. 202).

Meitar, Carmeli ve Waldman (2009)'a göre, işin anlamının kuramsal temelleri, sosyal kimlik kuramı ve özdeşlik kuramı ile açıklanabilmektedir. Sosyal kimlik kuramı, bireyin sosyal bir grubun üyesi olmakla kimlik kazandığını ve kendi rollerini ait olduğu sosyal grubun normlarına göre yeniden tanımladığını ve düzenlediğini savunmaktadır (Tajfel \& Turner,1985, s. 10). Böylece, aynı grup içindeki bireyler, örgütün bir parçası olarak onun amaçlarını, değerlerini ve inançlarını anlamlı bulmakta; kendilerini bu çerçevede tanımlayabilmekte ve böylece "anlam" kişisel kimliğin rol ve üyelik ile bütünleşmesi olarak açıklanmaktadır (Pratt \& Ashforth, 2003, s. 311). Özdeşlik kuramı ise, sosyal kimlik kuramından farklı yönde rol performansına yönelik anlam üzerinde yoğunlaşmaktadır. Diğer bir ifade ile özdeşlik kuramı çalışan bireyin örgüt içerisindeki rollerini yerine getirdiği süreçte sergilediği davranışların incelenmesidir (Stets \& Burke, 2000, s. 224).

Kuramlar temel alındığında, kişinin işte geçirdiği süre arttıkça yaşamlarında anlam yakalamada ve kimlik hissi sağlamada işin daha fazla merkezi özellik kazandığı söylenebilir (Hoar, 2004, s. 47). İşin Anlamı arayışııın giderek daha fazla merkezi konuma gelmesi ile birlikte akademik yazında da kavrama yönelik araştırma sayısındaki artış dikkat çekicidir. Araştırma sonuçları genel olarak yaşamın / işin anlamının psikolojik iyi oluş / mutluluk; iş motivasyonu; işte devamsızlık; iş davranışları; işe adanmışlık; iş tatmini; güçlendirme; psikolojik stres; örgütsel özdeşleşme; kariyer gelişimi; 
bireysel performans ile anlamlı ilişkileri ortaya koymaktadır (Rosso, Dekas \& Wrzesniewski, 2010, s. 93).

İşin anlamı üzerinde çalışmalar yapan araştırmacıların ortak görüşü; günümüzde çalışan bireyin yalnızca finansal açıdan değil, kişisel gelişim, kariyer olanakları, sosyal sorumluluk çerçevesinde de çalışma koşullarını değerlendirdiğidir. İşin Anlamı açısından gelinen noktada ABD'de tam zamanlı çalışma düzeninin giderek azalmakta olduğu, işgücünün özel yaşam ve diğer firsatları değerlendirebilecek şekilde işlerini tasarımlama eğiliminde olduğu, esnek ve yarı zamanlı çalışma oranının \%30'u bulduğu belirtilmektedir. Bireyin, çalışmayı yalnızca bir gelir aracı olarak değil, kendini gerçekleştirmesinin yollarından biri olarak gördüğü anlaşılmaktadır (Reich, 2001, s. 6).

Anlam arayışındaki işgücünün, örgüt performansına katkıda bulunmanın ötesinde öncelikle kendisine katkı sağlama ve yeteneklerini geliştirme isteğinin, çalışanın işyerinde uzun süre tutundurulmasını zorlaştırabileceği düşünülmektedir. Bu sebeple, işin anlamının tanımlanmasının hem işgücünün örgütte uzun süre tutundurulmasında hem de yüksek performans elde edilmesinde insan kaynakları politika ve uygulamalarını destekler yönde olumlu etkileri olacağına inanılmaktadır.

\section{2. İȘIN ANLAMININ ÖLÇÜMÜ}

Gerek uluslararası gerekse ulusal literatürde iş ve anlam ilişkisine yönelik çalışmalara giderek daha sık rastlanmaktadır. Farklı ülke kültürlerine mensup hizmet sektörü çalışanlarında işin anlamının öncüllerini araştırılmış ve iş ve çalışma ortamına yönelik algıların işin anlamını etkilediği sonucuna ulaşılmıştır (Dimitrov, 2012). Diğer bir araştırmada işin anlamının öncüllerinin; yetkinliklerin geliştirilmesi, yönetim ve iş arkadaşları tarafından desteklenme ve işe yönelik otonomi olduğunu ortaya çıkarılmıştır (Vuori, San \& Kira, 2012, 240). Başka bir çalışmada, işin anlamının dönüşümsel liderlik ve işe bağl1lık arasındaki ilişkide aracılık etkisi belirlenmiş (Ghadi, Fernando \& Caputi, 2013), ve aynı çalışmada çalışmada işin anlamını değerlendirmek için May ve arkadaşları tarafindan (May, Gilson \& Harter, 2004) geliştirilen ölçek kullanılmıştır. Diğer bir araştırmada, işin anlamının yaratıcılı̆̆ desteklediği öne sürülmüş ve işin anlamı, Pratt ve Asforth (2003) tarafindan kavramsallaştırılan "algılanan örgüt kimliği”, ve "algılanan dış prestij" olarak iki boyut ile ölçülmüştür (Meitar, Carmeli \& Waldman, 2009). Literatürde "anlam" kavramını psikolojik güçlendirme yaklaşımının boyutlarından biri olarak ele alan çalışmalara da rastlanmaktadır (De Cicco, Laschinger \& Kerr 2006, s. 53). Thomas ve Velthouse (1990) tarafından yeterlilik, anlamlılık, seçim ve etki şeklinde tanımlanan psikolojik güçlendirme boyutları; daha sonra Spreitzer (1995) tarafindan anlam, yeterlilik, özerklik ve etki olmak üzere yeniden tanımlamış ve bu boyutlara ilişkin bir ölçme aracı geliştirilmiştir. Zyl ve 
arkadaşları da (2010) işin anlamına yönelik çalışmalarında Spreitzer (1995)'in ölçeğinden yararlanmışlardır.

Son dönemde yapılan araştırmalar da işin anlamını yitirmesinin tükenmişlik sendromunun üç alt boyutundan biri olduğu ortaya konmuştur (Mashlach ve Leiter, 2016, s. 103). Ulusal yazında işin anlamı ile ilgili gerçekleştirilmiş olan çalışmalarda (örneğin: Çöl, 2008) Spreitzer (1995) tarafından geliştirilen üç ifadelik ölçeğin kullanıldı̆̆ görülmektedir. Akın ve arkadaşları (2013) ise, Steger ve arkadaşları (2012) tarafından geliştirilen "İşin Anlamı” ölçeğine geçerlik ve güvenirlik çalışması yapmışlardır. Ancak bu çalışmada farklı bir açıdan bakılmış, Keşfedici Faktör Analizi ile ölçeğin içindeki yap1 Türkiye örnekleminde yeniden ortaya çıkarılmış ve Steger ve arkadaşları (2012) tarafından kullanılan paralel ölçek test edilmiştir.

\section{YÖNTEM}

Dil geçerliliği için “İşin Anlamı Ölçeği”nin Türkçe’ye çevirisi ve ardından geri çevirisi yapılmıştır. Türkçeye çevirisi yapılırken, dildeki en uygun cümle yapısının kullanılmasına dikkat edilmiştir. İlk hali ile son çevirideki ifadeler karşılaştırılıp değerlendirilerek anlaşılabilirlik açısından en uygun ifadeler seçilmiştir. Araştırmanın evreni, beyaz yakalı çalışanlar olarak belirlenmiştir. Örneklem grubu, kolayda örnekleme yöntemi ile seçilen 229 Sigorta sektörü çalışanından oluşmaktadır. Basılmış anket formları, bırak-topla tekniği ile doldurtulmuştur. Anketi doldurmak istemeyen ve eksik dolduranlar çıkarıldıktan sonra 201 katılımcının kullanılabilir anket formu değerlendirmeye alınmıştır. Böylece ulaşılan çalışanlarda yaklaşık \%88 oranında temsil kabiliyetinde olduğu hesaplanabilmektedir.

\subsection{Sosyo-Demografik Dağılım}

Araştırmaya katılan çalışanların 20'si $(\% 10,0)$ 21-25 yaş, 89'u $(\% 44,3)$ 26-30 yaş, 58'i $(\% 28,9)$ 31-35 yaş, 34'ü $(\% 16,9) 36$ ve üstü yaş grubundadır. 108 'i $(\% 53,7)$ kadın, 93'ü $(\% 46,3)$ erkektir. 16's1 $(\% 8,0)$ lise ve önlisans, 138'i $(\% 68,7)$ lisans, 42 'si $(\% 20,9)$ yüksek lisans, 5'i $(\% 2,5)$ doktora mezunudur. 95 'i $(\% 47,3)$ evli, 106's1 $(\% 52,7)$ bekârdır. 69'u (\%34,3) çocuk sahibidir.

\subsection{Güvenilirlik ve Geçerlilik Analizleri}

Ölçekteki on ifadenin güvenirliği Özdamar (2004)'da önerildiği şekilde hesaplanmış ve iç tutarlılık katsayısı olan Cronbach's Alpha $=0,888$ olarak bulunmuştur. İkinci bir kriter olarak Spearman-Brown Katsayıs $=0,868$ ve Guttman Split-Half Katsayısı $=0,866$ olarak hesaplanmış ve iç tutarlılık sağlanması desteklenmiştir. Steger ve arkadaşlarının (2012) çalışmasında ortaya çıkardığı faktörlerin bu çalışmanın örneklemi için elde edilen iç tutarlılık katsayıları "pozitif anlam" boyutu için 0,77 ; "işin kattığ anlam" boyutu için 0,81 ve "yüksek motivasyon" boyutu için 0,65 olarak bulunmuştur. Madde- 
toplam korelasyonları ise 0,39 ile 0,81 arasında değişmekte ve Alpar (2010)'a göre 0,250 'den yüksek olma kriterini sağlamaktadır (Tablo 1).

Her bir maddenin, ölçeğin geneline katkısı yüksek ve anlamlıdır. Maddelerin ayırt ediciliklerini incelemek için Tablo 1'de madde bazında alt $\% 27^{\prime}$ lik ve üst \%27'lik dilim ortalamaları arasındaki fark için yapılan t testlerinin tümü anlamlıdır $(p<0,05)$. Madde ayırt edicilik gücünün yüksek olduğu görülmüştür.

Tablo 1: İşin Anlamı Ölçeği İçin Madde Analizi

\begin{tabular}{|c|c|c|}
\hline & $\begin{array}{c}\text { Madde- } \\
\text { toplam } \\
\text { korelasyonu }\end{array}$ & $\begin{array}{c}\text { Alt-Üst } \\
\% 27 \\
\text { t testi }\end{array}$ \\
\hline 1.Kariyerim benim için anlamlıdır. & 0,393 & $-14,87^{*}$ \\
\hline 2.İ̧sim kişisel gelişimimime katkı sağlar. & 0,701 & $-21,87 *$ \\
\hline 3.İsisim dünyaya herhangi bir fark katmaz. & 0,553 & $-25,45^{*}$ \\
\hline 4.İ̧̧imin hayatımın anlamına nasıl katkı sağladığını biliyorum. & 0,553 & $-20,04 *$ \\
\hline 5. İşimin anlamlı olduğuna dair olumlu hislerim var. & 0,808 & $-18,85^{*}$ \\
\hline $\begin{array}{l}\text { 6.İ̧̧imin hizmet verdiğim müş̧erilere olumlu katkı sağladığını } \\
\text { biliyorum. }\end{array}$ & 0,528 & $-17,43 *$ \\
\hline 7.İşim kendimi daha iyi anlamama yardım eder. & 0,645 & $-20,87 *$ \\
\hline 8. İşimin tatmin edici bir amacı vardır. & 0,767 & $-20,34 *$ \\
\hline 9.İ̧sim hayatımı anlamlı kılar. & 0,669 & $-22,00 *$ \\
\hline 10.Yaptığım iş büyük bir amaca hizmet eder. & 0,619 & $-23,52 *$ \\
\hline Cronbach's Alpha $=\% 88,8$ & \multicolumn{2}{|c|}{$*_{p}<0,05$} \\
\hline \multicolumn{3}{|l|}{ Spearman-Brown Katsaylsı $=\% 86,8$} \\
\hline \multicolumn{3}{|l|}{ Guttman Split-Half Katsaylsı $=\% 86,6$} \\
\hline \multicolumn{3}{|c|}{$\begin{array}{l}\text { Bu çalışmada ölçeğin, Türk kültüründe nasıl bir yapıya sahip olduğunu } \\
\text { incelemek için Çokluk vd. (2010)'da belirtildiği gibi maksadıyla keşfedici } \\
\text { faktör analizi ile ölçeğin yapısını doğrulamak için doğrulayıcı faktör analizine } \\
\text { tabi tutulmuştur. }\end{array}$} \\
\hline \multicolumn{3}{|c|}{$\begin{array}{l}\text { Faktör analizinin test edilebilmesi için ön varsayımlardan biri olan } \\
\text { Barlett testi sonucunda }(\mathrm{p}=0,000<0.05) \text { faktör analizine alınan değişkenler } \\
\text { arasında Büyüköztürk vd. }(2014) \text { 'da ifade edildiği gibi sıfırdan farklı anlamlı bir } \\
\text { ilişkinin olduğu tespit edilmiştir. }\end{array}$} \\
\hline \multicolumn{3}{|c|}{$\begin{array}{l}\text { KMO testi sonucunda }(\mathrm{KMO}=0,897>0,60) \text { Özdamar (2016)'a göre } \\
\text { örnek büyüklügünün faktör analizi uygulanması için yeterli olduğu tespit } \\
\text { edilmiştir. Faktör analizi uygulamasında Akgül ve Çevik (2005)'de olduğu gibi } \\
\text { bütün maddelerdeki maksimum varyansı açıklayabilmek için temel bileşenler } \\
\text { metodu tercih edilmiş, ayrıca Tabachnick ve Fidell (2012)'deki teoriye }\end{array}$} \\
\hline
\end{tabular}


dayandırılarak varimax rotasyonu seçilerek faktörler arasındaki ilişkinin yapısının aynı kalması sağlanmıştır.

Scree Plot

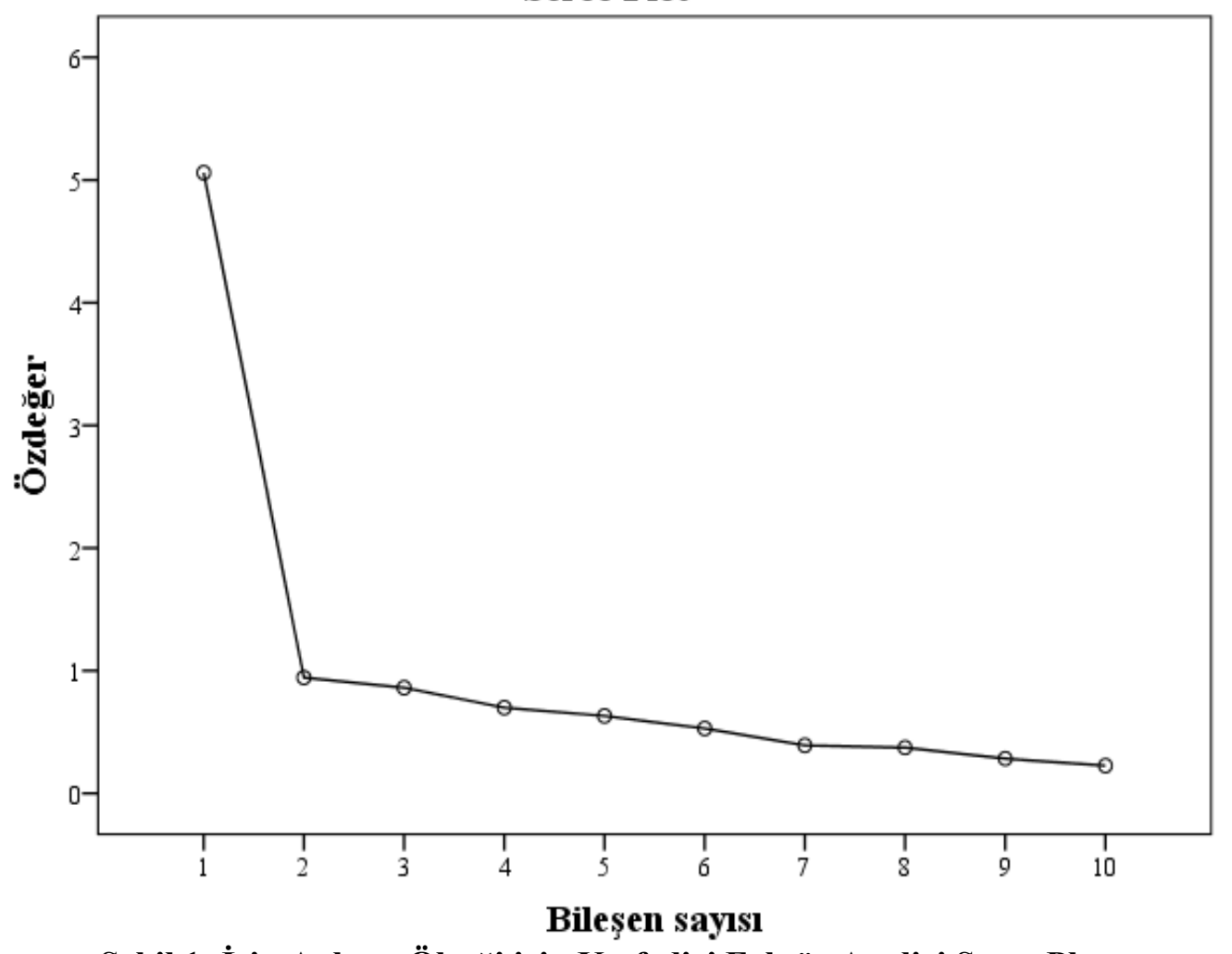

Şekil 1: İşin Anlamı Ölçeği için Keşfedici Faktör Analizi Scree Plot

Faktör analizi sonucunda maddeler toplam açıklanan varyansı \%50.6 olan tek faktör altında toplanmıştır ve varyans açıklama oranının tek faktör için Alpar (2010)'a göre \%50'nin üzerinde olmas1 sebebiyle yeterli olduğu görülmüştür. Ne Steger vd (2012) ne de Akın ve arkadaşları (2013) keşfedici faktör analizi bulgusu paylaşmamıştır. Bu çalışmada keşfedici faktör analizinde tek boyutlu bir yapı ortaya çıkmış, 2 ve 3 boyut denenmesine rağmen faktörlerde yer alan ifadelerin dağılımı, daha önceki çalışmalarda teorik olarak belirtilen benzer faktörlerde yer almamış ve isimlendirilememiştir.

Scree plot grafiğinden Şekil 1'de görüldügü üzere Özdamar (2016)'a göre 1'in üzerinde sadece bir özdeğer mevcuttur ve birinci bileşenden itibaren eğim çizgisinin düzleştiği görülmektedir. 


\begin{tabular}{lc}
\hline & $\begin{array}{c}\text { Faktör } \\
\text { yükü }\end{array}$ \\
\hline 1.Kariyerim benim için anlamlıdır. & 0,469 \\
2.İşim kişisel gelişimime katkı sağlar. & 0,776 \\
3.İşim dünyaya herhangi bir fark katmaz. \# & 0,638 \\
4.İşimin hayatımın anlamına nasıl katkı sağladığını biliyorum. & 0,636 \\
5.İşimin anlamlı olduğuna dair olumlu hislerim var. & 0,864 \\
6.İşimin hizmet verdiğim müşterilere olumlu katkı sağladığını biliyorum. & 0,614 \\
7.İşim kendimi daha iyi anlamama yardım eder. & 0,735 \\
8.İşimin tatmin edici bir amacı vardır. & 0,837 \\
9.İşim hayatımı anlamlı kılar. & 0,753 \\
10.Yaptığım iş büyük bir amaca hizmet eder. & 0,704 \\
\hline
\end{tabular}

Varyans açıklama oranı $=\% 50,6$

\# olumsuz madde, ters kodlanmıştır

İşin Anlamı ölçeğinin keşfedici faktör analizi değerlendirilmesinde (Tablo 2) faktör yükleri 0,469 ile 0,864 arasında değişmekte ve Çokluk ve arkadaşlarının (2010) verdiği kritere göre 0,30’un üzerindedir. Keşfedici faktör analizi sonucu ölçek yekpare bir yapıda olup, tek faktör ile açıklanabilmektedir.

Tablo 3: İşin Anlamı Ölçeği İçin Doğrulayıcı Faktör Analizi Uyum İyiliği Kriterleri

\begin{tabular}{lccc}
\hline Uyum iyiliği & $\begin{array}{c}\text { Kabul Edilebilir } \\
\text { Değer }\end{array}$ & $\begin{array}{c}\text { Tek Faktörlü Yapı İçin } \\
\text { Sonuçlar }\end{array}$ & $\begin{array}{c}\text { Üç Faktörlü Yapı İçin } \\
\text { Sonuçlar }\end{array}$ \\
\hline Ki-kare / SD & $<3$ & 2,95 & 2,35 \\
RMSEA & $<0,08$ & 0,099 & 0,082 \\
RMR & $<0,08$ & $(\% 90$ GA $=0,077-0,121)$ & $(\% 90$ GA $=0,058-0,107)$ \\
NFI & $>0,90$ & 0,050 & 0,044 \\
IFI & $>0,90$ & 0,89 & 0,92 \\
CFI & $>0,95$ & 0,92 & 0,95 \\
GFI & $>0,85$ & 0,92 & 0,93 \\
\hline
\end{tabular}

GA: Güven aralı̆̆

Türkiye örnekleminden elde edilen veri ile yapı geçerliliğini test etmek amacıyla yapılan doğrulayıcı faktör analizi uyum iyiliği kriterleri Tablo 3'te sirasiyla Ki-kare / SD = 2.95; RMSEA = $0.099(\% 90 \mathrm{GA}=0.077-0.121)$ SRMR $=0.050 ; \mathrm{NFI}=0.89 ; \mathrm{IFI}=0.92 ; \mathrm{GFI}=0.92 ; \mathrm{CFI}=0.91$ olarak 
hesaplanmıştır. Hem Steger hem de Akın tarafından elde edilen üç faktörlü yapı test edildiğinde ise uyum iyiliği kriterleri Tablo 3'te sirasıly Ki-kare / SD = 2.35; RMSEA $=0.082(\% 90 \mathrm{GA}=0.058-0.107) ; \mathrm{SRMR}=0.044 ; \mathrm{NFI}=0.92$; $\mathrm{IFI}=0.95 ; \mathrm{GFI}=0.93 ; \mathrm{CFI}=0.95$ şeklinde karşılaştırmalı olarak sunulmuştur. Uyum iyiliği kriterleri, gözlenen verinin hem tek faktörlü modele hem de üç faktörlü modele kabul edilebilir düzeyde uyum gösterdiğini ortaya koymaktadır (Tabachnick \& Fidell, 2012).

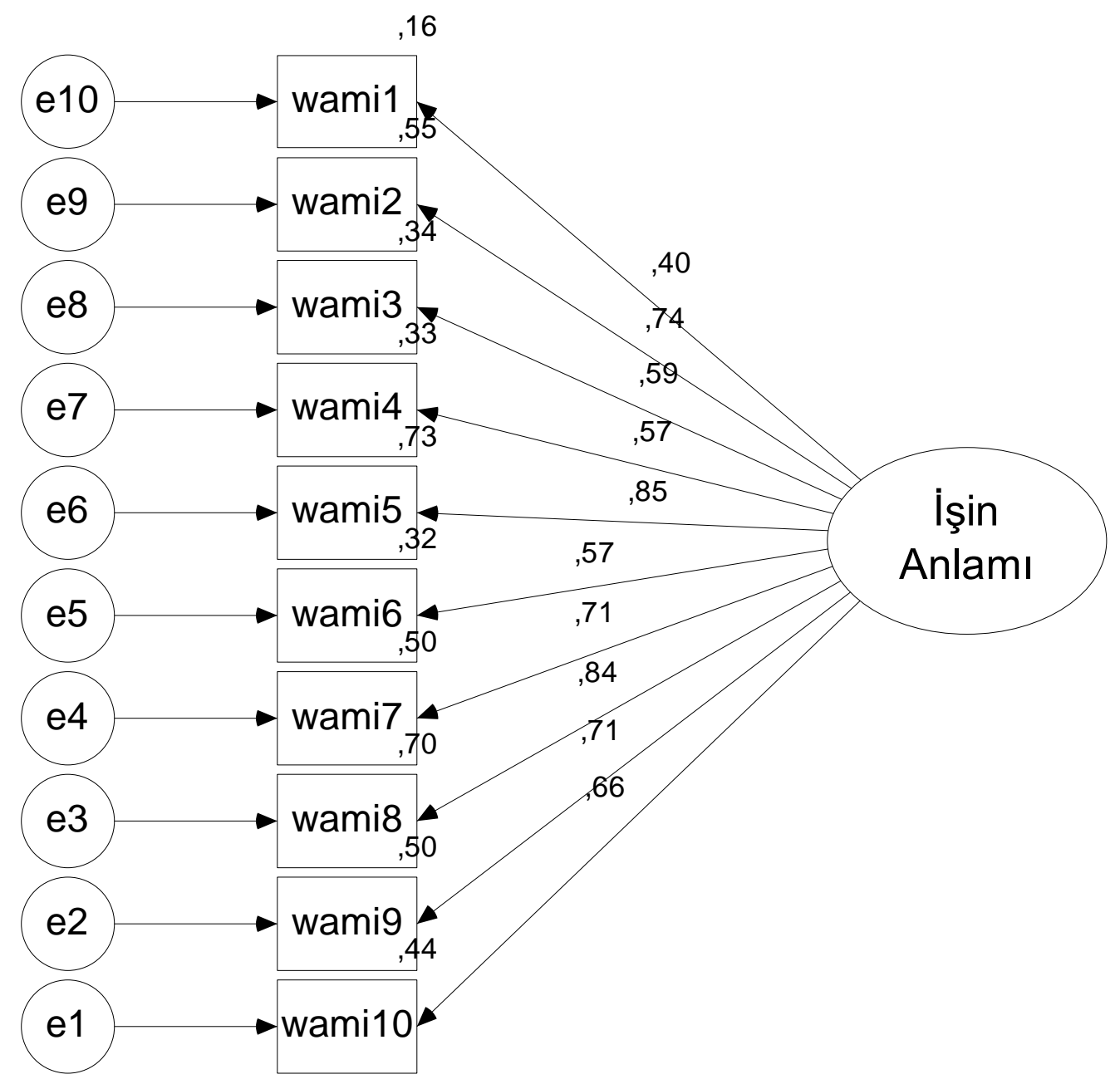

Şekil 2: İşin Anlamı Ölçeği İçin Doğrulayıcı Faktör Analizi

İşin Anlamı ölçeğinin doğrulayıcı faktör analizi bulgularında; hem tek faktörlü hem de üç faktörlü yapının faktör yüklerinin 0,40 ile 0,86 arasında 
değiştiği görülmektedir ve Bayram (2010)'a göre ölçüm modeli anlamlıdır $(\mathrm{p}=0,000<0,05)$.

Paralel test için literatür incelendiğinde, işin anlamını ölçmeye ikame olarak kullanılabilecek ve anlam olarak yakın bir ölçeğe rastlanmamıştır. Steger ve arkadaşları (2012) tarafından orijinal ölçek geliştirme çalışmasında da kullanılan Brayfield ve Rothe (1951) tarafından geliştirilen, 5 maddeden oluşan ve orjinal adı "Job Satisfaction Questionnaire" olan "İş Tatmini Ölçeği" uygulanmış ve Pearson Momentler Çarpımı Korelasyon Katsayısı hesaplanmıştır. Paralel form geçerliliği açısından Şekil 3 incelendiğinde; iş tatmini ile işin anlamı puanları arasında $\% 65$ düzeyinde pozitif yönde anlamlı korelasyon bulunmuştur $(\mathrm{p}=0,000<0,05)$. Buna göre iş tatmini puanı arttıkça işin anlamı puanı da artmaktadır. Tavşancıl (2014)'a göre Paralel ölçek geçerliliği sağlanmıştır.

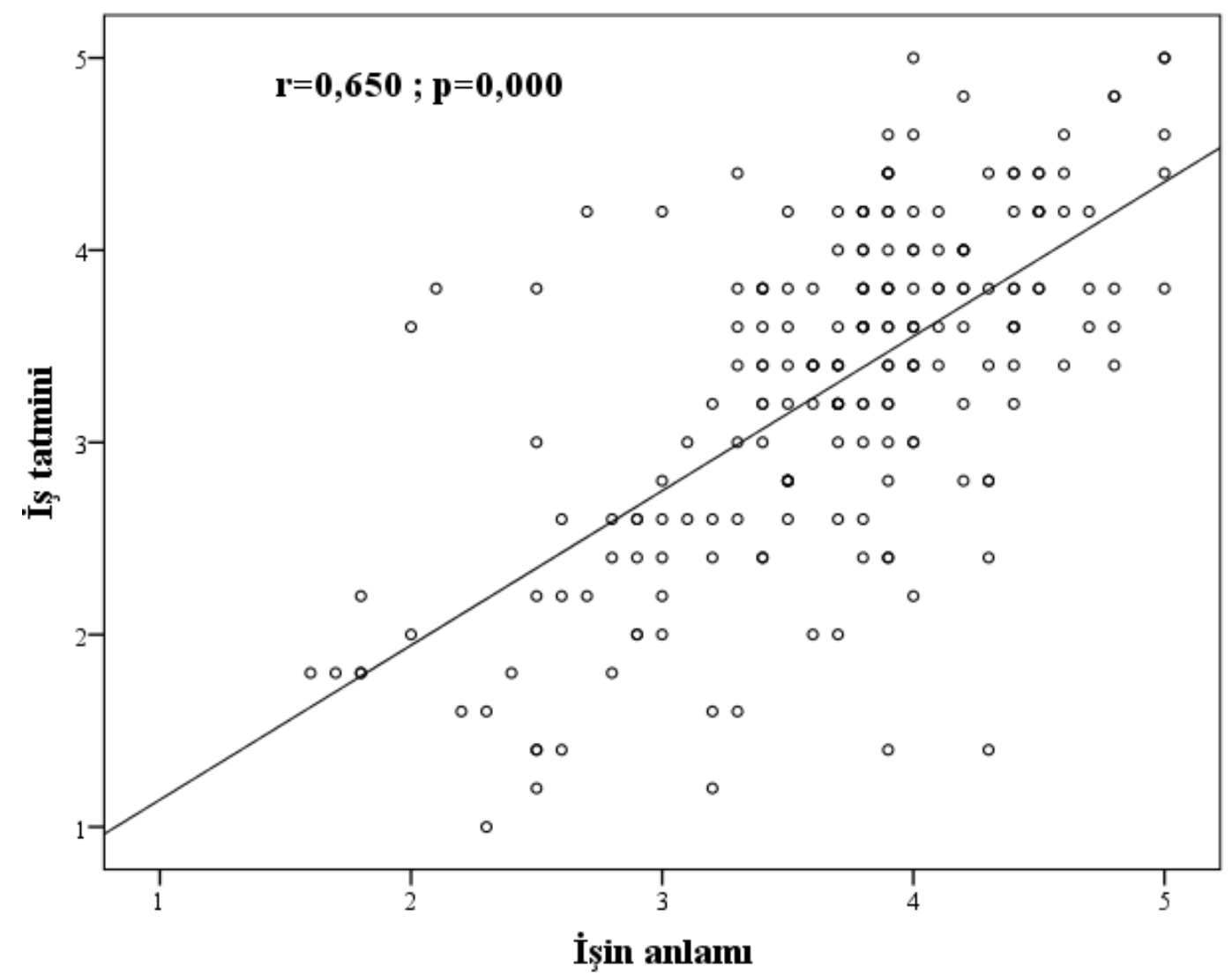

Şekil 3: Paralel Test Korelasyonu - İşin Anlamı İle İş Tatmini Arasındaki İlişkiye İlişkin Korelasyon Analizi 
Türkçe uyarlamasında, ölçeği geliştiren Steger ve arkadaşları (2012)'de olduğu gibi 5'li Likert Ölçek ${ }^{1}$ tercih edilmiştir. Ölçek sonuçları 5.00-1.00=4.00 puanlık bir genişliğe dağılmışlardır. Bu genişlik beşe bölünerek işin anlamı düzey aralıkları belirlenmiştir. Buna göre; 1.00-1.79 puan aralığı, "çok düşük", 1.80-2.59 "düşük", 2.60-3.39 "orta”, 3.40-4.19 "yüksek" ve 4.20-5.00 arası "çok yüksek" olarak değerlendirilmektedir. "İşin Anlamı Ölçeği”nin puanları hesaplanırken her bir katılımcının verdiği yanıt toplandıktan sonra madde sayısına bölünerek ölçek puanı elde edilmiştir.

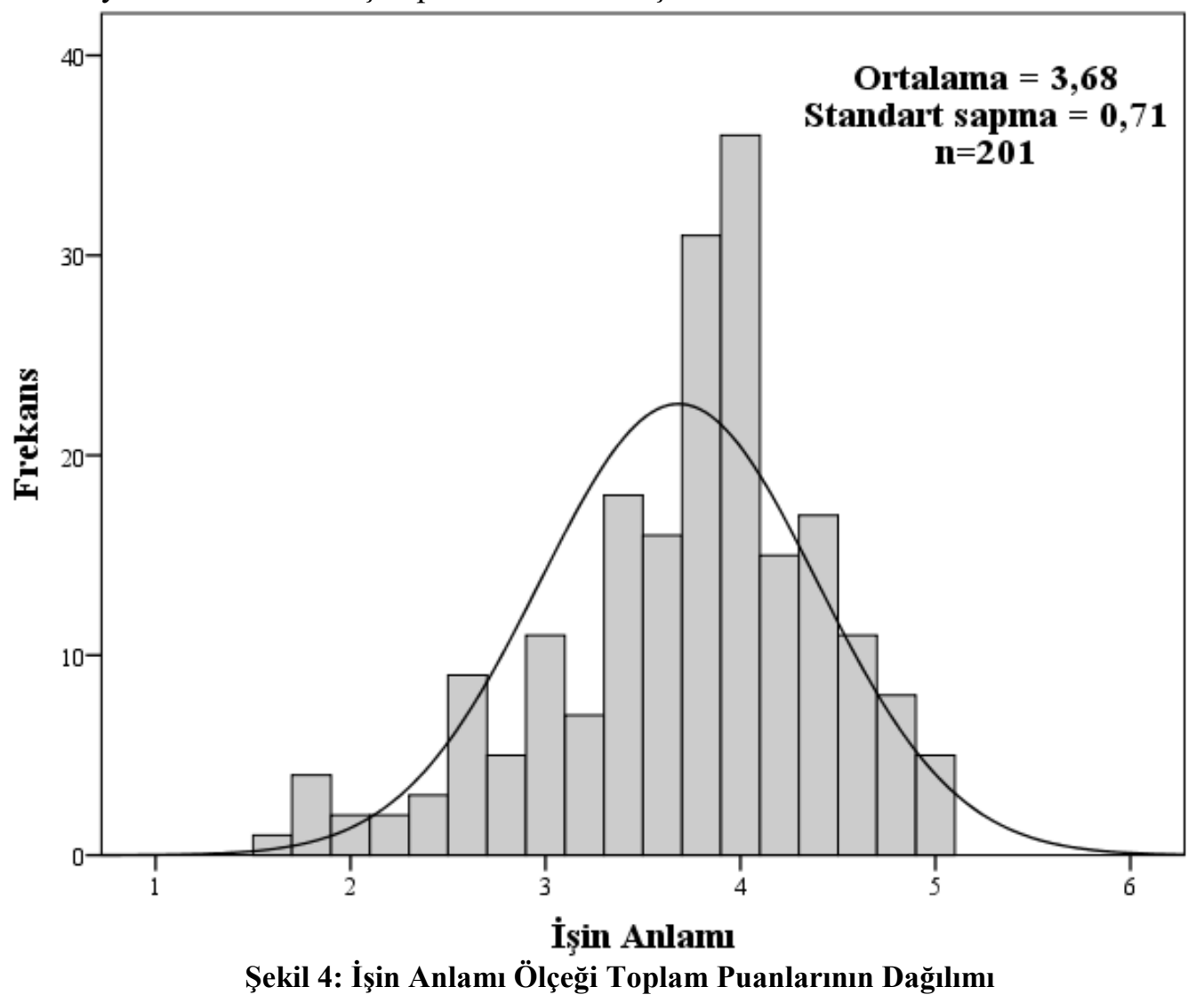

Ölçeğin yorumlanmasında, puan yükseldikçe kişinin işe yüklediği anlam artmakta, puan azaldıkça işe yüklediği anlamda azalmaktadır. Katılımcıların verdikleri yanıtlara göre "İşin Anlamı" ortalaması 3,68 $\pm 0,71$ (Minimum: 1,6 - Maksimum: 5) bulunmuştur (Şekil 4). Ortalamaların 4 puan

${ }^{1}$ (5) Kesinlikle Katılıyorum, (4) Katılıyorum, (3) Kararsızım, (2) Katılmıyorum, (1) Kesinlikle Katılmiyorum 
seviyesinde dağılmış olması çalışanların işe yüklediği anlamın yüksek olduğunun, çoğunlukla işlerine pozitif anlam yüklediklerinin bir göstergesidir. "Pozitif anlam" boyutu ortalaması 3,76 $\pm 0,75$; "İşin kattığı anlam" boyutu ortalamas 13,54 $\pm 0,86$; "Yüksek motivasyon" boyutu ortalamas1 3,72 $\pm 0,80$ bulunmuştur. En yüksek ortalamaya sahip alt boyutun pozitif anlam olduğu ancak tüm alt boyutların ortalamalarının 3,5 ile 4 arasında değer sahip olduğu ve işin anlamının alt boyutlarının da genel olarak yüksek olduğu görülmektedir.

\section{SONUÇ}

Günümüzde, "işletmeye piyasada rekabet avantaj1 sağlayan, işletme çalışanlarının bildiği her şeyin toplamı" olarak Stewart (1997, s. 72) tarafından tanımlanan entelektüel sermaye kavramının, çalışanların bilgi, yetenek ve yetkinliklerinin önemi akademik ve iş yaşamında kabul edilmiş durumdadır. Bunun doğal bir sonucu olarak, Du Toit (2003) bilgiyi yönetmek entelektüel sermayeyi bulup geliştirmek, saklamak, satmak, paylaşmak, bireyler, örgütler ve uluslar için öncelikli bir konu olarak kabul edilmektedir. Günümüz işletmelerinin rekebet gücünü belirleyen unsurların başında bilginin kendisi kadar ona sahip olan nitelikli bireylerin büyük bir öneme sahip olduğu bilinen bir gerçektir. Çalışanların işten ayrılmaları ile kaybedilen, bazıları eşsiz ve bireye özgü olan- bilgi, beceri, deneyim ve yeteneklerinden oluşan insan sermayesi Bontis ve Keow (2000)'a göre işletmelerin ortak yeteneği olarak tanımlanmaktadır. $\mathrm{Bu}$ ortak yetenek olan insan sermayesinin işletmeye bağl1lığını uzun yıllar korumak ve istihdam etmek ise işletme yönetimi açısından giderek dafa fazla zorlaşmaktadır. Rekabetçi ve ekonomik koşullar haricinde bunun sebeplerinden birisi de, Ünnü ve Kesken (2011)'e göre yaşanan sosyo-ekonomik gelişmelerle birlikte bireyin toplum ve iş yaşamı içerisindeki rollerini yeniden sorgulamasıdır, diğer bir ifade ile anlam arayışıdır.

Pozitif psikoloji bilim insanı M. Seligman'a göre (2002) anlamlı hayat, kişinin inandığı; anlamı ve değeri olan şeyi yapması ile ilgilidir. Buna göre Bakker ve Leiter (2010)'da çalışanların görev veya işlerini anlamlandırarak iş niteliklerini bilfiil değiştirebilecekleri düşünülmektedir. Demografik değişimler, küreselleşme ve teknolojik gelişmeler gibi son 20 yılda yaşanan dönüşümler çalışanların davranışlarını ve işlerine yönelik algılarını önemli ölçüde etkilemiştir. İşin Anlamı sadece fiziksel yaşamı devam ettirmeye yönelik değil, aynı zamanda sosyal ve psikolojik ihtiyaçları da sağlamaya yöneliktir. $\mathrm{Bu}$ bağlamda, Kapız (2001, s. 79)'a göre işin anlamı ve işlevleri öncelikle birey ve akabinde ailesi için daha da önemli hale gelmiştir. Birey, bütünsel bir bakış açısı ile hayattaki rollerini, amacını, yönünü, yaptığı işin değerini diğer bir ifade ile "anlamını" belirli dönemlerde sorgulayabilmektedir. Sonuç olarak, çalışan bireyin örgüte sadakatinin ve bağlılığının azalmaya başladığı, bunun yerine bireysel gelişime ve işe bağlılığa verilen önemin arttı̆̆ını gibi ifade etmek yanlış 
olmamakla birlikte işin anlamına yönelik tek taraflı bir bakış açısı sağlayacaktır (Keser, 2005, s. 263 ).

Çalışan bireyin talep ettiği ya da ihtiyaç gördüğü kişisel gelişim imkanlarını, kariyer gelişimini destekleyen uygulamaları veya iş özelliklerinin kendisine sağladığı otonomiyi sunarak, işin anlamını sorgulayan çalışanı kuruma uzun süreli kazandırmak insan kaynakları açısından yeni bir meydan okuma alanı olarak da kabul edilebilir. Cartwright ve Holmes (2006), İngiltere'de daha önceki yıllarda gerçekleștirilen araștırma sonuçlarının, çalışanların \%80'ninin kuruma hiçbir bağlılık hissetmeden çalıştığını ortaya çıkardığını belirtmektedir. Elde edilen bu sonuçların yanı sıra, bireylerin özel yaşamları da dahil olmak üzere çalıştıkları kurumlara adanmışlıklarını sağlayacak bir anlam arayışında oldukları ve buna ihtiyaç duydukları da araştırma bulgularında yer almaktadır. Özetle, iş-yaşam dengesinin sağlanmasında ve bireyin kendisini üretken, tatmin olmuş ve adanmış hissetmesinde işin anlamının önemli bir yeri olduğu sonucu ortaya çıkmaktadır.

Çalışanların hayattaki dengelerini yeniden yakalamalarında işin anlamının işletme yönetimi tarafindan yaratılabilmesi için uygulamalar yapılırken, işin anlamını ölçebilmek için geçerli ve güvenilir araçların belirlenmesi de son derece önemli olmaktadır. Türkçe literatürde "İşin Anlamlılı̆̆ı" ile ilgili ölçüm aracı araştırılmış olup, Türkçe kullanılabilecek bir ölçeğe rastlanmamıştır. İngilizce elde edilen alt boyutların Türkçe karşıllı̆ı tam olarak ortaya konmadan kullanılması durumunda, eğitim seviyesi düşük çalışanlar ya da İngilizce bilmeyen araştırmacılar tarafından ölçüm aracının kullanılmasının zor olduğu düşünülmektedir. Bu çerçevede "İşin Anlamı" ölçeğinin Türkiye örnekleminde Türkçe literatüre kazandırılması amaçlanmıştır.

Steger, Dik ve Duffy (2012) tarafından geliştirilen ve Akın ve arkadaşları (2013) tarafından çalışılan "Work and Meaning Inventory"de yer alan ve bu çalışmada "İş̧in Anlamı" olarak Türkçe ifade edilen ölçeğin Dil Geçerliliği yapılmıştır.

On maddenin ölçek toplamına katkısı pozitif yönlü ve yüksek düzeydedir. Ölçekte dokuz madde pozitif anlam taşırken, "İşim dünyaya herhangi bir fark katmaz" olumsuz ifadesi, kullanım açısından dikkat edilmesi ve ters kodlanarak ölçeğe katkı yapması gereken bir maddedir. Bu durum avantaja dönüştürülerek, ölçeğin güvenilirliğinin kontrol edilmesi açısından katk1 sağlanabilir. Bu madde için madde-toplam korelasyonu düşük çıkmış olsaydı, katılımcıların 10 soruya arka arkaya tesadüfi olarak yanıt vermiş olabilecekleri sonucuna varılabilirdi. Bu açıdan 3 numaralı maddenin kontrol sorusu olarak değerlendirilebileceği düşünülmektedir. Faktör yükü en düşük $(0,40)$ olan "1.Kariyerim benim için anlamlıdır." maddesi incelendiğinde; diğer maddelerden farklı bir içeriğe sahip olduğu, yapılan işten ziyade kişinin 
kariyerine ilişkin anlamı sorguladığı dikkat çekmektedir. Steger ve arkadaşları (2012) tarafindan yapılan faktör analizinde bu madde en yüksek faktör yüküne sahipken $(0,92)$, Akın ve arkadaşları (2013) tarafından yapılan faktör analizinde bu madde bizim çalışmamıza benzer şekilde en düşük faktör yüküne $(0,35)$ sahip olmuştur. $\mathrm{Bu}$ bulgu Türk örnekleminde, yurtdışının aksine kariyer aracılığı ile algılanan iş anlamının, işe yüklenen anlamdan daha önemsiz olduğunu göstermektedir.

$\mathrm{Bu}$ çalışmada Cronbach's Alpha $=0,88$ katsayıs1, Steger ve arkadaşlarının (2012) çalışmasında bulunan Cronbach's Alpha=0,93 değerine ile Akın ve arkadaşlarının (2013) çalışmasında bulunan Cronbach's Alpha=0,93 değerine yakın bulunmuştur. Ancak alt boyut güvenilirlikleri karşılaştırıldığında iki çalışmada da tüm alt boyutlar için \%80'in üzerindeyken, bu çalışmada "Pozitif anlam" alt boyutu için 0,77 ve "Yüksek motivasyon" alt boyutu için 0,65 şeklinde daha düşük iç tutarlılığa sahip olduğu dikkat çekmektedir. Bu bulgu, keşfedici faktör analizinde 3 faktörlü bir yapı elde edilememesi ile paralel bir sonuç göstermektedir.

Benzer (paralel) ölçek geçerliliği, iş tatmini ile sınanmış olup, korelasyon analizi sonucu beklendiği gibi anlamlı bulunmuştur. Akın ve arkadaşları (2013) paralel geçerlilik için "İ̧s Becerikliliği Ölçeğì" kullanmışlar ve \%41 düzeyinde korelasyon katsayısına ulaşmışlardır. Steger ve arkadaşlarının (2012) çalışmasında korelasyon katsayısı \%62 bulunmuşken, bu çalışmada \%65 bulunması Türk kültüründe işin anlamlılığ 1 ile iş tatmininin yüksek ilişkili olduğunu ancak iş becerikliliği ile daha düşük ilişki içinde olduğunu göstermektedir.

Açıklanan varyans oranı \%50'nin üzerinde bulunmuş olup, ölçeğin tek bir toplam puanla ifade edilebilmesini destekler niteliktedir. Hem keşfedici hem de doğrulayıcı faktör analizinde faktör yük değerleri ve madde-toplam korelasyonlarının yüksek olması, ölçeğin güçlü bir faktör yapısına sahip olduğunu göstermiştir.

Steger ve arkadaşlarının (2012) çalışmasında ölçeğin teorik olarak "1.Kariyerim benim için anlamlıdır", "4.İ̧̧imin hayatımın anlamına nasıl katkı sağladığını biliyorum", 5.İşimin anlamlı olduğuna dair olumlu hislerim var" ve "8.İşimin tatmin edici bir amacı vardır." maddelerinin pozitif anlam (positive meaning) ;" 2.İşim kişisel gelişimime katkı sağlar", "7.İşim kendimi daha iyi anlamama yardım eder" ve "9. İşim hayatımı anlamlı kılar" maddelerinin işin kattığı anlam (meaning making through work) ve son olarak "3. İşim dünyaya herhangi bir fark katmaz", "6.İşimin hizmet verdiğim müşterilere olumlu katkı sağladığını biliyorum" ve "10.Yaptığım iş büyük bir amaca hizmet eder" maddelerinin yüksek motivasyon (greater good motivations) olarak isimlendirilen 3 faktörden oluştuğunu belirtmiş ve Doğrulayıcı Faktör Analizi 
ile test etmiştir. Akın ve arkadaşlarının (2013) çalışmasında da aynı boyutlar ilgili örneklem üzerinden test edilmiştir. İfadeler incelendiğinde ise tüm soruların tek bir odak noktası olduğu ve faktör isimlerinin birbirine yakın olduğu anlaşılmaktadır. Ölçek tek bir toplam puan ile ifade edilebilmekte ve ölçekten alınan yüksek puan, işin anlamına dair değerlendirmenin pozitif anlamda yüksek olduğunu göstermektedir. Ölçeğin toplam puandan ziyade ortalama puan alınarak hesaplanması yorum açısından kolaylık sağlamaktadır. Normal dağılıma uygunluğu ise istatistik açıdan parametrik yöntemler ile analiz edilmesini ve yorumlanmasını kolaylaştırmaktadır.

Araştırmanın kısıtllıkları, test-tekrar test için katılımcılara ulaşılamaması ve kapsam geçerliliğinin eksik yapılmış olmasıdır. Yapılan istatistiksel analizler sonucunda söz konusu ölçeğin ülkemiz için hem 10 sorudan oluşan tek faktörlü yapının hem de üç faktörden oluşan alt boyutların geçerli ve güvenilir olduğu görülmüştür. Ancak alt boyutların kullanılmasında dikkatli olunması ve kullanmadan önce mutlaka iç tutarlılığının ve faktör yapısının örneklem üzerinden yeniden analiz edilerek yorumlanmasına özen gösterilmelidir.

\section{KAYNAKÇA}

Akın, A., Hamedoğlu, M. A., Kaya, Ç., \& Sariçam, H. (2013). Turkish version of the work and meaning inventory (Wami): validity and reliability study. Journal of European Education, 3(2), 11-16.

Akgül, A., \& Çevik, O. (2005). Istatistiksel veri analizi: spss'te ışletme yönetimi uygulamaları. Ankara: Mustafa Kitabevi.

Alpar, R. (2010). Uygulamalı istatistik ve geçerlilik - güvenilirlik. Ankara: Detay Yayınc1lik.

Bahadir, A. (2000). Psikoterapide yeni bir yaklaşım: logoterapi ve viktor frankl. Uludağ Üniversitesi Illahiyat Fakültesi Dergisi, 9(9), 2.

Bakker, A. B., \& Leiter, M.P. (2010). Work engagement: a handbook of essential theory and research. New York: Taylor \& Francis.

Bayram, N. (2010). Yapısal eşitlik modellemesine giriş amos uygulamaları. Bursa: Ezgi Yayınevi.

Bontis, N., Keow, W. C. C. \& Richardson, S. (2000). Intellectual capital and business performance in malaysian industries. Journal of Intellectual Capital, 1(1), 85100 .

Brayfield, A., \& Rothe, H. (1951). An index of Job satisfaction. Journal Of Applied Psychology, 5, 307-311.

Büyüköztürk, Ş., Kılıç Çakmak, E., Akgün, Ö. E., Karadeniz, Ş. \& Demirel, F. (2014). Bilimsel araştırma yöntemleri. Ankara: Pegem Akademi.

Chartwright, S., \& Holmes, N. (2006). The Meaning Of Work: The challenge of regaining employee engagement And reducing cynicism. Human Resource Management Review, 16, 199-208.

Çokluk, Ö., Şekercioğlu, G. \& Büyüköztürk, Ş. (2010), Sosyal bilimler için çok değişkenli istatistik: spss ve lisrel uygulamaları. Ankara: Pegem Akademi. 
Çöl, G. (2008). Algılanan güçlendirmenin 1̧̧gören performansı üzerine etkileri. Doğuş Üniversitesi Dergisi, 9 (1), 35-46.

De Cicco, J., Laschinger, H. \& Kerr, M. (2006). Perceptions Of empowerment and respect: effect on nurses organizational commitment in nursing homes. Journal Of Gerontological Nursing, 49-56.

Dimitrov, D. (2012). Sources of meaningfulness in the workplace: a study in the us hospitality sector. European Journal Of Training And Development, 36(2), 351 -371 .

Du Toit, A. (2003). Competitive intelligence in the knowledge economy: what is in it for south african manufacturing enterprises?. International Journal of Information Management, 23(1), 111-120.

Feldman, D.B., \& Snyder, C.R. (2005). Hope and the meaningful life: theoretical and empirical associations between goal-directed thinking and life meaning. Journal of Social And Clinical Psychology, 24(3), 401-421.

Frankl, V. E. (1984), Man's search for meaning. New York: Pocket Books.

Garner, H., \& Meda, D. (2006). La Place du travail dans l'identité des personnes, données sociales. La Société Française, 623-63.

Ghadi, M.Y., Fernando, M., \& Caputi, P. (2013). Transformational leadership and work engagement. Leadership \& Organization Development Journal, 34(6), 532 550 .

Hoar, R. (2004). Work with meaning. Management Today, May, 44-50.

Kapiz, S.Ö. (2001). İşin değişen anlamı ve birey yaşamında önemi. Isş, Güç Endüstri İliskkileri ve Insan Kaynakları Dergisi, 3(2), 78-89.

Kesken, J., \& Ünnü, N. A. (2011). Öteki Liderlik. Ankara: Gazi Kitabevi.

Keser, A. (2005). Çalışmanın değişen anlamı ve çalışmaya ilişkin trendler. Işs, Güç, Endüstri İlişkileri ve Insan Kaynakları Dergisi, 49, 261-379.

Mashlach, C., \& Leiter M. P. (2016). Understanting the burnout experience: recent research and its implications psychiatry. World Psychiatry, 15(2), 103-11.

May, D.R., Gilson, R.L. \& Harter, L.M. (2004). The psychological conditions of meaningfulness, safety and availability and the engagement of the human spirit at work. Journal Of Occupational And Organizational Psychology, 77(1), 1137.

Meitar, R.C., Carmeli, A. \& Waldman, D.A. (2009). Linking meaningfulness in the workplace to employee creativity: The Intervening role of organizational 1dentification and positive psychological experiences. Creatıvity Research Journal, 21(4), 361-375.

Melton, A.M.A., \& Schulenberg, S.E. (2008). On the measurement of meaning: logotherapy's empirical ontributions to humanistic psychology. The Humanistic Psychologist, 36, 31-44.

Mendes, F., \& Stander, M.W. (2011). Positive Organization: The role of leader behaviour in work engagement and retention. Journal Of Industrial Psychology, 37(1), 1-13.

Morin, E. (2008). Sens Du Travail, Santé mentale et engagement organisationnel, Santé Psychologique Études Et Recherches. Rapport R-543 Irsst. 
Nielsen, K., Randall, R., Yarker, J. \& Brenner, S. O. (2008). The effects of transformational leadership on followers' perceived work characteristics and psychological well-being: a longitudinal study. Work And Stress, 22 (1), 16-32.

Özdamar, K. (2004). Paket Programlar ile İstatistiksel Veri Analizi. Eskişehir: Kaan Kitabevi.

Özdamar, K. (2016). Ĕ̈itim, sağllk ve davranış bilimlerinde ölçek ve test geliştirme yapısal eşitlik modellemesi. Eskişehir: Nisan Kitabevi.

Pahl, R. (1994). After success, fin-de siècle anxiety and ldentity. Cambridge: Polity Press.

Pratt, M.G., \& Ashforth, B.E. (2003). Fostering meaningfulness in working and at work. İçinde Cameron, K.S., Dutton, J.E. \& Quinn, R.E. (Eds), Positive organizational scholarship, Foundations Of A New Discipline, San Francisco, Ca: Berrett-Koehler Publishers, 309-327.

Seligman, M. E. P. (2002). Authentic happiness. London: Nicholas Brealey Publishing.

Reich, R. B. (2001). The future of success working and livind in the new economy. New York: Vintagebooks.

Rosso, B.D., Dekas, K.H. \& Wrzesniewski, A. (2010). On The Meaning Of Work: A Theoretical integration and review. research in organizational behavior, 30 , 91-127.

Sezer, S. (2012). Yaşamın anlamı konusuna kuramsal ve psikometrik çalışmalar açısından bir bakış. Ankara Üniversitesi Eğitim Bilimleri Fakültesi Dergisi, (45) $1,212$.

Spreitzer, G.M. (1995). Psychological empowerment in the workplace : Dimensions, measurement, and validation. Academy Of Management Journal, 38(5), 14421465 .

Steger, M. F., Kashdan, T. B. , Sullivan, B. A. \& Lorentz, D. (2008). Understanding the search for meaning in life: personality, Cognitive style and the dynamic between seeking and experiencing meaning. Journal of Personality, 76(2), 199-228.

Steger, M. F., Dik, B. J. \& Duffy, R. D. (2012). Measuring meaningful work: the work and meaning inventory (Wami). Journal of Career Assessment, 00(0), 1-16.

Stets, Jan E., \& Burke, P. J. (2000). Identity theory and social identity theory. Social Psychology Quarterly, 63(3), 224-237.

Stewart, A.T. (1997). Entellektüel Sermaye: kuruluşların yeni zenginliği, Çev: Nurettin Elhüseyni, Mess Yayın No: 258, 72

Tabachnick, B., \& Fidell, L. (2012). Using multivariate statistics. Boston: Pearson Education.

Tajfel, H., \& Turner, J. (1985). The social identity theory of intergroup behavior, içinde Worchel, S. \& Austin,W. (Eds.), Psychology of inter-group relations, (2), Chicago, Nelson-Hall, 7-24.

Tavşancıl, E. (2014). Tutumların ölçülmesi ve SPSS ile veri analizi. Ankara: Nobel Akademik Yayıncilık.

Thomas, K. W., \& Velthouse, B. A. (1990). Cognitive elements of empowerment: an "1nterpretive" model of intrinsic task motivation. The Academy Of Management Review, 15 (4), 666 - 681.

\section{2}


Vuori, T., San, E., \& Kira, M. (2012). Meaningfulness-making at work. qualitative research in organizations and management. An International Journal, 7(2), 231 -248 .

Zyl, L.E., Deacon, E., \& Rothmann, S. (2010). Towards happiness: experiences of work-role fit, meaningfulness and work engagement of industrial/organizational psychologists in south africa. Sa Journal Of Industrial Psychology, 36(1). 